\title{
Patterns of Fairness Judgments in North America and the People's Republic of China
}

\author{
Wen-Qiang Bian and L. Robin Keller \\ Graduate School of Management \\ University of California, Irvine
}

\begin{abstract}
This article covers the results of 5 surveys conducted in the United States, Canada, and the People's Republic of China. These surveys illustrate the differences and similarities of ethical tradeoff patterns regarding fairness between North Americans and Chinese, in situations concerning health and safery risks and in situations involving pricing of a variety of goods and services under a number of market settings. Although the results are tied to special contexts, the general pattern of findings is quite clear. On health and safety issues, American graduate business students in California were found to make decisions consistent with their faimess judgments in health and safety risk settings. In contrast, the fairness judgments of Chinese graduate business students do not necessarily coincide with their own decisions in the same health and safety situations. On marketplace issues, responses of members of the Canadian public, in addition to recognizing market forces, demonstrate significant concern for the protection of consumers' interests, whereas market principles appear to dominate most of the responses of Chinese and Californian graduate business students. These results provide valuable insights for multinational businesses involved in North American-Chinese joint ventures when developing strategies on pricing, negotiations, and bidding on environmentally sensitive projects.
\end{abstract}

For many years, ethical issues in business operations have received serious government and public attention in North America. General and specialized government regulations have been enacted to protect consumers on many fronts, such as requiring employer contributions for compensating injured workers and laws protecting credit card users from delinquency when there are disputed charges. The public has 
also organized to protect against violations of consumers' environmental and economic rights by powerful businesses. For example, movie star Mel Gibson's endorsement of the legal defense fund "Earthjustice" was recently covered in the popular press ${ }^{1}$ with a feature story that the fund helped two Louisiana communities win their battle against a multinational corporation that wanted to install a potentially hazardous nuclear waste facility there. In California, widely varying retail milk prices have recently come under scrutiny of a consumer group (Groves, 1998; "In O.C.," 1998; Mulkern, 1998).

However, such government and public sensitivity to ethical issues that may affect large numbers of people has not received similar attention in China. For example, in China's Sichuan Province, a little-contested government decision has ordered more than a million local residents to relocate to build the giant Three-Gorges hydroelectric dam, cutting the biggest river in China into two halves. In the consumer market, when consumers buy a malfunctioning television set, they usually have to absorb the loss by themselves. The situation may be better if they are in a handful of large cities, but the best they could expect still involves going through much anxiety and patience to obtain a replacement.

The aforementioned contrasts between North America and China led us to investigate how graduate business students in the two locales, as consumers and future executives, would respond to scenarios involving fairness judgments on health and safety issues and on consumers' economic transactions. Our work is part of a research program to investigate the transferability of decision analysis techniques and behavioral decision theory experimental survey results beyond their Western origins to China. A previous decision analysis study aimed at modeling people's preferences in societal health and safety risk scenarios by Keller and Sarin (1988) provided benchmark data on American graduate business students' judgments on fairness in health and safety risks. A behavioral decision theory study by Kahneman, Knetsch, and Thaler (1986) provided benchmark data on the Canadian public's fairness judgments in economic transactions. Similarities or differences between our Chinese respondents and the benchmark respondents may be due to cultural differences or professional background, or other differences in the participants or their environments.

Because our aim is to stimulate further research in consumer psychology examining similarities and differences between North Americans and Chinese on ethical issues involving environmental and economic outcomes, we chose to present a sampling of results from separate, related studies. Our findings are presented and then discussed in light of some possible national or professional culture explanations and some current events in the studied countries.

North America and China epitomize the so-called Western and Eastern cultures. Many culturally distinctive features can easily be found in the details of peo-

\footnotetext{
'In the July 14, 1997 issue of People magazine.
} 
ple's everyday lives. For example, the collective Chinese often treat in-group community members and out-group members differently, including in a business setting, whereas the individualistic North Americans purportedly do not make such a differentiation. Traditionally, the Chinese, as a suppressed and economically deprived population, tend to accept rather than challenge disadvantageous or unfair situations (Yau, 1994). Also, the Chinese are considered to be context dependent (Cateora, 1993; Hall, 1976) in making decisions, whereas the North Americans rely more on absolute rules (Hsieh, 1967).

Just as national culture may lead to differences in responses, so can the "corporate culture" of a profession. There is some evidence that people with business education or interests differ from others on fairness judgments and behaviors. Frank, Gilovich, and Regan (1993) presented a number of cases in which people with economics backgrounds differ from others in fairness and cooperation. Baron, Gowda, and Kunreuther (1993) found different attitudes toward managing hazardous waste across professions, and when Keller and Sarin (1995) gave American graduate business students hypothetical scenarios resulting in different allocations of risks and benefits between communities, they tended to attempt to maximize the utility of affected communities, whereas American undergraduate psychology students tended to attempt to fairly balance the risks and benefits equally between communities.

Markoczy $(1997,1998)$ cautioned against using national, cultural, or other demographic characteristics to make group generalizations in place of measuring cognition and recognizing individual differences within groups. We see our work as laying a foundation for the future by discovering similarities and differences within and across groups. For brevity, we generally focus on majority opinions within groups but always report percentages of respondents giving each response, which reveals individual differences within groups. Markoczy's advice is important and fits well with our ultimate goal: to develop techniques for aiding decision analyses in China that would allow individuals to specify their individual preferences to guide decisions.

This article covers the results of five surveys that investigated different aspects of people's fairness perceptions in the United States of America, Canada, and the People's Republic of China. In the Fairness in Health and Safety Risks section, we discuss decisions with health and safety risks (including results in Bian \& Keller, in press; Keller \& Sarin, 1988). In the Fairness Standards in the Marketplace section, we discuss fairness in consumers' daily lives (including results of Bian \& Keller, 1999; Kahneman, Knetsch, \& Thaler, 1986; plus a new survey), and the Discussion section provides further comments.

\section{FAIRNESS IN HEALTH AND SAFETY RISKS}

The perceptions of safety and environmental issues across countries, ethnic groups, and individuals have been explored by many decision scholars (e.g., Irwin, Jones, 
\& Mundo, 1996; Irwin, Slovic, Lichtenstein, \& McClelland, 1993; Sokolowska \& Tyszka, 1995; Vaughan \& Nordenstam, 1991). Our research findings indicate that differences in ethical tradeoff attitudes also exist in this area. Keller and Sarin (1988) conducted, in a written survey, hypothetical decision-making exercises using full-time, American Master's in Business Administration students in California as participants in scenarios that involve health and safety risks. They found that the majorities of American participants consistently considered situations in which "everyone has the same chance to live or die" to be "fair" across all scenarios, and that principle was followed by majorities of the participants who were asked to make "what-to-do" decisions. Bian and Keller (in press) duplicated this written survey in China, also using full-time graduate management students as participants. The results show that, although most Chinese appeared to agree with the American majority on what is fair, many times they do not choose the fairer option when making decisions. These results can be illuminating for businesses that involve possible health and safety risks to their customers or workers, such as electric and gas utilities and the health care industry. The following hypothetical survey problem involves a risk of fatalities to a whole community.

\section{Serum Producing Scenario}

One hundred islanders were born highly susceptible to contracting a fatal disease. Recently, it was discovered that the presence of a naturally occurring noxious gas led to this condition and the gas has been eradicated. However, there is still some chance of the islanders contracting the disease and thus dying. You could decide to give an injection to all 100 islanders. This injection will prevent everyone from contracting the disease. However, the serum for the injection can only be obtained from the blood of a person who has artificially been made to contract the fatal disease. The serum cannot be obtained from a person who has naturally contracted the disease, so you can't just wait to see if one person contracts the disease and then make the serum from the sick person's blood.

If one islander is sacrificed by being made to contract the disease, enough serum will be obtained to eliminate the risk of death to the remaining 99 islanders.

If nothing is done, there is a $1 \%$ chance of an epidemic breaking out in which all 100 islanders will contract the disease and thus die. There is a $99 \%$ chance that no epidemic will break out, so all 100 islanders will live.

The two options are summarized below.

Version A Task: Circle the option which is fairer.

Version B Task: Circle your choice.

Equal Option. Do nothing, and thus take a $1 \%$ chance of all 100 islanders dying. 
Unequal Option. Sacrifice l islander. (Keller \& Sarin, 1988, Scenario 1$)^{2}$

The responses are presented in Table 1. Clearly, in the equal option each person has an equal probability to live or die. This is considered fairer by a large majority of the participants, Americans (92\%) and Chinese (94\%) alike. However, although the majority of American participants ( $87 \%$ ) chose this as a decision, most Chinese participants chose significantly differently (proportions are different at $p<.0001$ level, two-tailed test, $z=7.2$ ), with $71 \%$ choosing the less fair unequal option in which one person is sure to die, whereas the other 99 persons are sure to live. ${ }^{3}$

Bian and Keller (in press) suggested some possible reasons behind the differences. First, Chinese are generally risk averse when facing potential losses, which resulted in their tendency to avoid extremely bad outcomes (catastrophes such as all 100 persons dying in the Serum Producing Scenario). Furthermore, individualistic Americans tend to give high priority to valuing individual human lives, whereas the collectivist Chinese many times are willing to subordinate that value in favor of a benefit shared by the whole group. In fact, people will even volunteer to sacrifice themselves for the group. Reflecting this collectivism in a managerial setting, Ralston, Gustafson, Elsass, Cheung, and Terpstra (1992) found Chinese managers to be more "human hearted" than American managers, with harmony of the group and sympathy for members of the group being important aspects of Chinese morality.

TABLE 1

Serum Producing Scenario

\begin{tabular}{|c|c|c|c|c|}
\hline \multirow[b]{2}{*}{$\begin{array}{l}\text { Percentage of Graduate Business } \\
\text { Students Selecting Each Option }\end{array}$} & \multicolumn{2}{|c|}{ In California } & \multicolumn{2}{|c|}{ In China } \\
\hline & $\begin{array}{l}\text { Which Is Fairer } \\
\text { Option?a }\end{array}$ & $\begin{array}{c}\text { What Is Your } \\
\text { Choice? }\end{array}$ & $\begin{array}{c}\text { Which Is Fairer } \\
\text { Option?c }\end{array}$ & $\begin{array}{l}\text { What Is Your } \\
\text { Choice?d }\end{array}$ \\
\hline Equal option & 92 & 87 & 94 & 29 \\
\hline Unequal option & 8 & 13 & 6 & 71 \\
\hline
\end{tabular}

${ }^{\mathrm{a}} n=53 .{ }^{\mathrm{b}} n=53 .{ }^{\mathrm{c}} n=51 .{ }^{\mathrm{d}} n=47$.

\footnotetext{
2Participants received either the Version A fairness judgment task or the Version B choice task. The title of the scenario (Serum Producing) and the options (equal or unequal) were not given to participants.

${ }^{3}$ In subsequent presentations of this scenario in graduate business student classes in California, many Asian-background and non-Asian-background students have been amazed that the other group chooses opposite from them.
} 
Although our hypothetical scenario is a simplification of reality, it can help shed light on real situations involving health and safety risks. For example, in Wuhan, China, an elderly man recently took a great risk to himself to provide a benefit to his entire town's population. He jumped into the swollen Yangtze River to plug a hole in a levee with his own body during the peaking of the river during the flood season, averting a disastrous flood in his town and averting the loss of many lives (Chu, 1998). ${ }^{4}$ In the United States, the press often covers extraordinary rescue efforts to save an individual, such as a trapped child.

Also, the ethical trade-off between economic benefits to an entire group and health and safety risks to a few may be more often decided in favor of economic benefits in China. In 1996, a rocket from southern China's Xichang Satellite Launch Center crashed during launch, killed at least 100 Chinese in a nearby village, and destroyed a $\$ 200$-million U.S. satellite. Following the crash, the Intelsat satellite consortium solicited a report that revealed the high fatality risks involved. Engineer Daniel Lilienstein wrote that Chinese launch facilities "fell short of the world standards in most areas.... Every time you launch, you stand a good chance of killing someone. ... This kind of callous disregard for human life is unconscionable" (Diamond, 1998).

\section{FAIRNESS STANDARDS IN THE MARKETPLACE}

In this section, we discuss the fairness of actions of consumers and service providers. Kahneman et al. (1986) conducted telephone surveys in the Canadian metropolitan areas of Toronto and Vancouver to investigate rules of fairness that apply to price setting by firms in product, labor, and housing markets. They found that fairness plays a significant role in determining whether Canadian consumers were willing to accept firms' pricing strategies and suggested that violating fairness is detrimental to the cause of the firms in the long run.

We gave the same survey questions (replacing Canadian dollars in the questions with Chinese currency) to graduate business students in the major Chinese business center and port city of Shanghai in 1995 (for details, see Bian \& Keller, 1999). Comparing the results of the two surveys, we found that:

- The Canadian public considered it unfair to increase a firm's profit, when it has strengthened market power, by passing its gain on to its customers as an additional cost on top of the reference price. However, the Chinese business students considered it acceptable.

\footnotetext{
${ }^{4}$ Other Yangtze River areas lost over 2,000 lives and millions were made homeless during this same flood season.
} 
- Both the Chinese business students and the Canadian public considered it acceptable to protect a firm's reference profit by passing its loss on to its customers.

- Both groups were affected by framing effects in their fairness judging process.

Based on these findings, we then asked what if the differences we found were not due to the different countries' cultures, but due to other factors. Specifically, the Canadian participants were members of the public responding in telephone interviews, and the Chinese were business students with written surveys. One possible reason for the differences (beyond country location) could have been the academic background and aspirations, and another could have been the survey response mode. As described at the beginning of this article, people in business and economics have been found to differ from those with other backgrounds in some other studies. We had two specific hints that people with business backgrounds may respond differently from the Canadian public. First, when we presented these results at European and North American conference and university seminars, often a Western-background audience member with a business or economics background would say the Chinese pattern of responses to marketplace questions was most appealing. Second, Kunreuther (1986) mentioned in his commentary on the original Canadian data by Kahneman et al. (1986) that an informal query of University of Pennsylvania's Wharton business students did not replicate all the Canadian results; the Wharton business student pattern on price increase scenarios was similar to our Chinese students but was not similar on a wage reduction scenario.

We decided to match the Chinese business student survey response mode and participant pool by collecting additional written survey data from 56 graduate business students in California. The characteristics of these students are summarized in the Appendix.

After having found striking differences between graduate business students on the health and safety questions presented in the previous section, we were somewhat surprised to find that, when asked about marketplace scenarios, graduate business students in China and California exhibited fairly similar patterns, which contrasted with the Canadian public's responses. Some of the results for the Canadian public and the graduate business students in both China and California are presented in the next three subsections.

\section{Protect Reference Price}

(Monopoly Scenario) A grocery chain has stores in many communities. Most of them face competition from other groceries. In one community the chain has no competition. Although its costs and volume of sales are the same there as elsewhere, the chain sets prices that average 5 percent higher than in other communities. (Kahneman et al., 1986, Problem 13) 
In this problem, the grocery chain took advantage of its monopoly power in the community compared to other communities where it has competitors by increasing its prices (and hence its profits) and passing this gain on as an additional cost to the customers. As seen in Table 2 , such activity was considered unfair by a majority $(76 \%)$ of the Canadian respondents but acceptable by majorities $(75 \%$ and $71 \%$ ) of the Chinese and American business student participants. (These differences in proportions stating unfair are significant at the $p<.0001$ level, $z=9.2$, for the Canadian-Chinese and 6.3 for the Canadian-American difference. ${ }^{5}$ ) It appears that the Canadians considered the prices of the chain in other communities as the prices to which the customers are entitled (called a reference price in Kahneman et al., 1986). On the other hand, the business students' data seem to imply that they have a more flexible attitude in judging a reference price that can vary according to the specific market situation.

In fact, the reference price is part of a more general concept named the reference transaction in Kahneman et al. (1986). Two other concepts included under the reference transaction category are reference wages and reference rents. Just like a reference price is relative to a merchant-customer relationship, a reference wage is relative to an employer-employee relationship, and a reference rent is relative to a landlord-tenant relationship.

TABLE 2

Monopoly Scenario

\begin{tabular}{|c|c|c|c|c|c|}
\hline \multirow[b]{3}{*}{$\begin{array}{l}\text { Percentage Judging } \\
\text { This as: }\end{array}$} & \multirow{3}{*}{$\frac{\text { General Public }}{\text { In Canada }}$} & \multicolumn{4}{|c|}{ Graduate Business Students } \\
\hline & & \multicolumn{3}{|c|}{ In California } & In China \\
\hline & & $\begin{array}{c}\text { American or } \\
\text { European Home } e^{b}\end{array}$ & $\begin{array}{l}\text { Home Country } \\
\text { Is in Asia }\end{array}$ & Total $^{d}$ & $\begin{array}{c}\text { China Is Home } \\
\text { Country }\end{array}$ \\
\hline Acceptable & 24 & 69 & 75 & 71 & 75 \\
\hline Unfair & 76 & 31 & 25 & 29 & 25 \\
\hline
\end{tabular}

${ }^{\mathrm{a}} n=101 .{ }^{\mathrm{h}} n=35 .{ }^{\mathrm{c}} n=20 .{ }^{\mathrm{d}} n=55 .{ }^{\mathrm{c}} n=150$.

\footnotetext{
${ }^{5}$ Most statistical tests are reported for the entire group of American business students because the two subgroups' responses are generally similar. The titles of the remaining scenarios are in parentheses (here the title is Monopoly Scenario). These titles were not given to survey participants. In the Protect Reference Price section, one participant with an American home country did not make a response, so the total number of American participants is 55, whereas in the remaining scenarios it is 56 . Home countries (preceded by numbers of people) in Asia were 5 China, 1 Hong Kong, 1 Singapore, 6 Taiwan, 1 Japan, 2 Korea, 3 India, and 1 Thailand. American and European culture home countries were 28 United States, 2 Canada, 1 Germany, 1 Austria, 2 Turkey, 1 Brazil, and 1 Australia.
} 


\section{Protect Business Interest}

(Lettuce Shortage Scenario) Suppose that, due to a transportation mix up, there is a local shortage of lettuce and the wholesale price has increased. A local grocer has bought the usual quantity of lettuce at a price that is 30 cents (3 yuan) per head higher than normal. The grocer raises the price of lettuce to customers by 30 cents ( 3 yuan) per head. (Kahneman et al., 1986, Problem 7; monetary units were Canadian cents, American cents, and Chinese yuan)

As shown in Table 3, the decision of the store to raise prices by the same amount that its cost increases was considered as unfair by only a small percentage of the Canadian respondents $(21 \%)$ and significantly fewer (at $p<.002$ ) of the business participants (5\% of the Americans and $3 \%$ of the Chinese). The action that maintains the firm's previous profit (vs. increases the firm's profit like in the Monopoly Scenario) at the expense of the customers is accepted not only by most of the Chinese and American business students but also by most of the Canadians. Such previous profit of a firm was called the reference profit in Kahneman et al. (1986), and apparently, most of the Chinese and North Americans use a similar (vs. significantly different in the Monopoly Scenario) criterion in judging the kind of reference profit to which a firm should be entitled. Consistent with this, our 1997 telephone survey in Shanghai and Jinan (for details, see Bian \& Keller, 1999) found that most Chinese public respondents considered fair and quite acceptable the actual current major cost-driven price increases on goods and services such as rice, railway travel, and household utilities.

Combining the results of both scenarios, we can see that the majority of Chinese and American business participants allowed a firm not only to protect its reference profits but also to raise this reference profit when the market condition shifts, both at the expense of its customers' reference transactions. However, the majority of the Canadian public respondents only allow the firm to protect its reference profits, but not to raise them. Some reasons that could be behind the difference between the Canadians and the Chinese are that the Chinese are very economically oriented

TABLE 3

Lettuce Shortage Scenario

\begin{tabular}{|c|c|c|c|c|c|}
\hline \multirow[b]{3}{*}{$\begin{array}{l}\text { Percentage Judging } \\
\text { This as: }\end{array}$} & \multirow{3}{*}{$\frac{\text { General Public }}{\text { In Canada }}$} & \multicolumn{4}{|c|}{ Graduate Business Students } \\
\hline & & \multicolumn{3}{|c|}{ In California } & \multirow{2}{*}{$\begin{array}{c}\text { In China } \\
\begin{array}{c}\text { China ls Home } \\
\text { Country }\end{array}\end{array}$} \\
\hline & & $\begin{array}{c}\text { American or } \\
\text { European Home }\end{array}$ & $\begin{array}{l}\text { Home Country } \\
\text { Is in Asiar }\end{array}$ & Total $^{d}$ & \\
\hline Acceptable & 79 & 100 & 85 & 95 & 97 \\
\hline Unfair & 21 & 0 & 15 & 5 & 3 \\
\hline
\end{tabular}

${ }^{a} n=101 .{ }^{\mathrm{b}} n=36 .{ }^{\mathrm{c}} n=20 .{ }^{\mathrm{d}} n=56 .{ }^{\mathrm{e}} n=150$. 
because of the recent economic development, and the Chinese tend to accept unfair situations because of their cultural traditions. Apparently, the American business students share the economic orientation of the Chinese business students. In fact, a written comment from one American survey participant was: "My economics background explains my answer."

Although our hypothetical pricing scenarios are simplifications of reality, they can help shed light on real situations involving economic reference transactions. For example, North American consumer groups frame debates on fair prices in terms of such reference transactions as those in these scenarios. California milk prices were recently found to be higher in supermarket chains than in small corner markets. Supermarket business executives respond matter-of-factly that the farm price went up and thus the retail price went up (implying that they need to protect their reference profit). However, in a press report on a Consumer Union study of California milk prices (see Groves, 1998), the study author Elisa Odabashian complained about retailers' pricing practices:

Retailers use any increase in the farm price as an excuse to raise the retail price of milk even higher than the farm price increase, and then often fail to pass on to consumers their full savings when the farm price goes down. (pp. D1, D8)

\section{Framing Effect}

Various forms of framing effects and their impact on people's perceptions and decision making have been studied in previous research studies, such as Irwin's (1994) environmental changes; Wagenaar, Keren, and Lichtenstein's (1988) surface and deep structures; and Yu's (1991) habitual domains. It is not a surprise that our findings showed that framing, or presenting the same basic problem differently, affects people's fairness perceptions in all three countries.

\section{Workers' Compensation Scenario}

Version A (Wage Reduction). A small company employs several people.

The workers' incomes have been about average for the community. In recent months, business for the company has not increased as it had before. The owners reduce the workers' wages by 10 percent for the next year.

Version B (Bonus Elimination). A small company employs several people. The workers have been receiving a 10 percent annual bonus each year and their total incomes have been about average for the community. In recent months, business for the company has not increased as it had before. The owners eliminate the workers' bonus for the year. (Kahneman et al., 1986, Problem 6) 
In both Versions A and B, the company reduced its workers' income by $10 \%$. However, this reduction is in the form of a wage cut in Version $A$ but in a cancellation of a bonus in Version B; the former can be framed as a loss, and the latter can be seen as the elimination of a potential gain to the employees. Table 4 contains the results. The majority of North Americans found the wage reduction unfair. Californian students with an American or European culture home country had the highest proportion $(81 \%)$, and Canadians had a significantly smaller $(p=.014)$ majority of $61 \%$, whereas American students with home countries in Asia had a similar majority of $60 \%$. In contrast, significantly differently $(p<.0003)$, the majority of Chinese accept the wage reduction. So, in this scenario, the majority of people in North America responded the same, rather than business students responding the same. One American-born business participant wrote, "My opinion about profits on consumer goods is much different than [on] labor. Consumers have more flexibility in decision making in consumer goods than they do as employees of companies."

Beyond the percentages accepting the wage reduction in Version A, we see that an added $37 \%$ of Chinese, $41 \%$ of Canadian, and $64 \%$ of American respondents accepted the bonus elimination in Version B. (Tests show significant differences in the proportion responding with "acceptable" in Versions A and B at $p<.0001$ for all three groups. $)^{6}$ This shows how influential the presentation or framing of a situation can be to people's marketplace fairness judgments.

TABLE 4

Workers' Compensation Scenario

\begin{tabular}{|c|c|c|c|c|c|}
\hline & \multirow{3}{*}{$\frac{\text { General Public }}{\text { In Canada }}$} & \multicolumn{4}{|c|}{ Graduate Business Students } \\
\hline & & \multicolumn{3}{|c|}{ In California } & \multirow{2}{*}{$\frac{\text { In China }}{\begin{array}{c}\text { China Is Home } \\
\text { Countryt }\end{array}}$} \\
\hline & & $\begin{array}{c}\text { American or } \\
\text { European Home }\end{array}$ & $\begin{array}{l}\text { Home Country } \\
\text { Is in Asia }\end{array}$ & Total & \\
\hline \multicolumn{6}{|c|}{ Version A: Wage reduction } \\
\hline Acceptable & $39^{\circ}$ & 19 & 40 & 27 & 62 \\
\hline Unfair & $61^{e}$ & 81 & 60 & 73 & 38 \\
\hline \multicolumn{6}{|c|}{ Version B: Bonus elimination } \\
\hline Acceptable & $80^{f}$ & 92 & 90 & 91 & 99 \\
\hline Unfair & $20^{f}$ & 8 & 10 & 9 & 1 \\
\hline
\end{tabular}

${ }^{\mathrm{n}} n=36 .{ }^{\mathrm{b}} n=20 .{ }^{\mathrm{c}} n=56 .{ }^{\mathrm{d}} n=150 .{ }^{\mathrm{e}} n=100 .{ }^{\mathrm{r}} n=98$.

\footnotetext{
${ }^{6}$ It should be noted that in Kahneman et al. (1986), different respondents answered Versions A and B, whereas in our business student surveys in China and the United States, the same respondents answered both Versions $A$ and $B$. It would be more likely for the business respondents to detect the equivalence of Versions $A$ and $B$ because they saw both of them. The fact that there exists a significant difference between the answers to Versions $A$ and $B$ by the business student respondents indicates the level of influence of the change in frame from a wage reduction to cancellation of a bonus.
} 


\section{Tipping by Consumers}

In addition to what actions by firms were considered to be fair, we also investigated the participants' expectations of how they themselves would behave when giving restaurant tips. Tipping is a long-standing custom in North America, but it is new in China, and it is perceived as an extra cost rather than as a gesture to show appreciation to the servers.

Version A (Frequent Restaurant). If the service is satisfactory, how much of a tip do you think most people leave after ordering a meal costing $\$ 10(100$ yuan) in a restaurant that they visit frequently?

Version B (Out-of-Town Restaurant). ... in a restaurant on a trip to another city that they do not expect to visit again? (Kahneman et al., 1986, Problem 17) ${ }^{7}$

As seen in Table 5, our Chinese business students offer substantially smaller tips (averages of $4.97 \%$ and $6.2 \%$ ) than the Canadians (averages of $12.7 \%$ and $12.8 \%$ ) and the American business students (averages of $18.4 \%$ and $13.4 \%$ ). Most notably, business students in both China and the United States tip less (by $20 \%$ and $27 \%$ of the tip given in the regular restaurant, respectively) in a restaurant that they would not visit again than in a restaurant they visit frequently, whereas the Canadians tipped a consistent amount. So, the business students appear to vary their tipping action depending on the situation, whereas the Canadian public appear to apply an absolute rule regardless of locale. Among the students in California, for every extra 10 years the person had lived in the United States, the tip given while in a restaurant they will not visit again increased by 14 cents, or $1.4 \%$ of the $\$ 10$ bill, but having an Asian home country was not significant. ${ }^{8}$

\section{Ethics of People in Business}

In the previous section, we saw that Chinese and American business students varied their tips by whether it is a restaurant that they visit frequently or a restaurant that they will not visit again, displaying an accepting attitude toward differential treat-

\footnotetext{
${ }^{7}$ In the Tipping by Consumers and Ethics of People in Business sections, the Chinese and the American respondents answered both Versions $A$ and $B$ of the same problem, whereas the Canadian respondents answered either Version $\mathrm{A}$ or $\mathrm{B}$.

${ }^{8}$ Overall regression model, $F(3,52)=4.13, p<.01$, with the variable of number of years in the United States significant at $p=.0034$, but variables for having a business major as an undergraduate or having an Asian home country not significant.
} 
TABLE 5

Tipping Scenario

\begin{tabular}{|c|c|c|c|c|c|}
\hline & \multirow{3}{*}{$\frac{\text { General Public }}{\text { In Canada }}$} & \multicolumn{4}{|c|}{ Graduate Business Students } \\
\hline & & \multicolumn{3}{|c|}{ In California } & \multirow{2}{*}{$\begin{array}{c}\text { In China } \\
\begin{array}{c}\text { China Is Home } \\
\text { Country }\end{array}\end{array}$} \\
\hline & & $\begin{array}{c}\text { American or } \\
\text { European Home }\end{array}$ & $\begin{array}{l}\text { Home Country } \\
\text { Is in Asia }\end{array}$ & Total & \\
\hline \multicolumn{6}{|l|}{ Frequent restaurant } \\
\hline Mean response & $\begin{array}{l}\$ 1.28(12.8 \% \\
\text { of bill })^{\mathrm{e}}\end{array}$ & $\begin{array}{l}\$ 1.89(18.9 \% \\
\text { of bill })\end{array}$ & $\begin{array}{l}\$ 1.75(17.5 \% \\
\text { of bill })\end{array}$ & $\begin{array}{l}\$ 1.84(18.4 \% \\
\text { of bill) }\end{array}$ & $\begin{array}{l}6.2 \text { yuan }(6.2 \% \\
\text { of bill) }\end{array}$ \\
\hline \multicolumn{6}{|l|}{ Out-of-town restaurant } \\
\hline Mean response & $\begin{array}{l}\$ 1.27(12.7 \% \\
\text { of bill })^{\mathrm{i}}\end{array}$ & $\begin{array}{l}\$ 1.38(13.8 \% \\
\text { of bill) }\end{array}$ & $\begin{array}{l}\$ 1.27(12.7 \% \\
\text { of bill) }\end{array}$ & $\begin{array}{l}\$ 1.34(13.4 \% \\
\text { of bill) }\end{array}$ & $\begin{array}{l}4.97 \text { yuan } \\
(4.97 \% \text { of bill) }\end{array}$ \\
\hline $\begin{array}{l}\text { Premium paid to } \\
\text { frequent restaurant ( } \% \\
\text { bill and } \% \text { frequent tip) }\end{array}$ & $\begin{array}{l}\$ .01(0.1 \% \text { of } \\
\text { bill and } 0.8 \% \\
\text { of tip })^{f}\end{array}$ & $\begin{array}{l}\$ .51(5.1 \% \text { of } \\
\text { bill and } 27 \% \\
\text { of tip) }\end{array}$ & $\begin{array}{l}\$ .48(4.8 \% \text { of } \\
\text { bill and } 27 \% \\
\text { of tip) }\end{array}$ & $\begin{array}{l}\$ .50(5.0 \% \text { of } \\
\text { bill and } \\
27 \% \text { of tip) }\end{array}$ & $\begin{array}{l}1.23 \text { yuan } \\
(1.23 \% \text { of bill } \\
\text { and } 20 \% \text { of tip) }\end{array}$ \\
\hline
\end{tabular}

${ }^{\mathrm{a}} n=36 .{ }^{\mathrm{h}} n=20 .{ }^{\mathrm{c}} n=56 .{ }^{\mathrm{d}} n=150 .{ }^{\mathrm{c}} n=124 .{ }^{\mathrm{\digamma}} n=98$.

ment. Another kind of acceptance of differential treatment is reflected in the following situations.

Mechanic Version A (North American version). A man leaves his car with the mechanic at his regular/A tourist leaves his car at a service station with instructions to replace an expensive part. After the [customer/tourist] leaves, the mechanic examines the car and discovers that it is not necessary to replace the part; it can be repaired cheaply. The mechanic would make much more money by replacing the part than by repairing it. Assuming the [customer/tourist / can not be reached, what do you think the mechanic would do in this situation?

Mechanic Version A (Chinese version). A man leaves his bike with the mechanic at his regular/A tourist leaves his bike at a service station with instructions to replace an expensive part. After the [customer/tourist] leaves, the mechanic examines the bike and discovers that it is not necessary to replace the part; it can be repaired cheaply. The mechanic would make much more money by replacing the part than by repairing it. Assuming the [customer/tourist / can not be reached, what do you think the mechanic would do in this situation?

Mechanic Version B. Of ten mechanics dealing with a [regular customer/tourist], how many would you expect to save the customer money by repairing the part? (Kahneman et al., 1986, Problems 18-19) 
In Version A, the mechanic could make one of two choices: Repairing the part leads to the benefit of pleasing the client and establishing a good reputation. However, because the tourist would not come back, the mechanic would not eventually benefit from such goodwill. Replacing the part carries the benefit of cashing in without offending the client.

Two action patterns by mechanics would be consistent with a profit orientation. First, for the sake of the current profits, the mechanic might replace the part, whether the client was his or her regular customer or a tourist. Second, the mechanic might repair for his regular customer but not for the tourist, because the regular customer has long-term value but the tourist does not.

As seen in Table 6, about $60 \%$ of the Canadian public thought the mechanic would replace the part to make more money from both his or her regular customer and a tourist. On the other hand, the business students made a distinction between the two types of customers. The majority (89\% of Chinese and 59\% of American business participants) thought the mechanic would kindly repair the part if the client was his or her regular customer, and $85 \%$ and $73 \%$, respectively, thought he would go for the profit and replace the part if the client was a tourist. (This difference is significant at $p \leq .0003$ for both Chinese and American business participants.)

The same pattern was found again in Version B, in which the business participants appeared to think that many mechanics would differentiate between the regular customer and the tourist. An average of 6.8 (for Chinese participants) and 4.3 (for American participants) out of 10 mechanics were foreseen to repair the regular customer's part, but only 2.3 (for Chinese participants) and 2.5 (for American participants) out of 10 were predicted to repair the tourist's part. In contrast, the Canadian respondents did not expect such differential treatment but did expect only 3.6 or 3.7 out of 10 mechanics would try to save the clients money by repairing the part. The Canadian responses seem to be consistent with other studies (e.g., Bian \& Keller, in press) that found the North Americans follow the doctrine that "every individual should be treated equally" that is deeply rooted in their individualistic cultural tradition. However, both the American and Chinese business students appeared to expect mechanics to give this up for better current profits.

Other studies such as Leung and Bond (1984) and Hui, Triandis, and Yee (1991) have suggested that the Chinese tend to treat in-group members and out-group strangers differently. Specifically, the Chinese do more favors for their in-group members, as part of the custom called guanxi. Although the Canadian public respondents expected their people in business would not extend favors differently between the regular and tourist clients, the Chinese and American business students expected mechanics to extend favors to regular customers who might be viewed as their in-group members and at the same time treat the out-group strangers the same way as the Canadians. According to Trompenaars (1994), those following universal rules and those giving differential treatments might criticize the others' ethics, the first saying that "they cannot be trusted because they will al- 


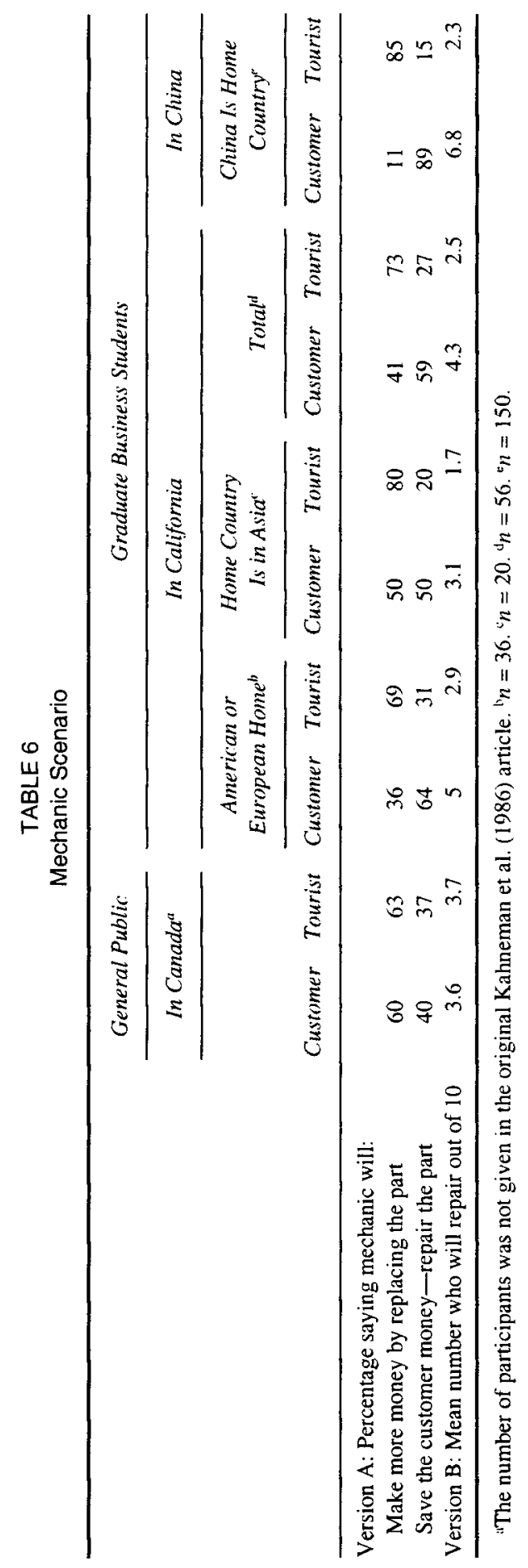


ways help their friends," and the second saying "you cannot trust them; they would not even help a friend."

Ambler (1994) argued that the relational marketing paradigm, in which cooperation within social or other relationships is a prime way to market goods and services, is more prominent in China than in the West. However, a sizeable number of our Western business participants responded differently for regular customers and tourists, so the relational marketing paradigm, or "network capitalism" described in Boisot and Child (1996), may also apply in the United States, at least for business students' expectations about mechanics' services. In fact, in China there are two different pricing systems for goods and services, with lower prices for Chinese and higher prices for foreigners. This may be an extreme form of relational marketing.

\section{DISCUSSION}

All people have their own sense of fairness, and this may influence their behavior in a wide range of situations, including scenarios affecting health and safety and transactions in the economic marketplace. We reported similarities and differences in responses to a set of surveys of the Canadian public and graduate business students in the United States and China.

When health and safety risks were involved, we found that graduate business students in the United States and China seemed to have very close fairness opinions; however, the Americans tended to follow these opinions when making decisions, whereas many Chinese did not.

We then conducted a study that asked about a number of common marketplace scenarios to see whether the differences we found between North Americans and Chinese on the health and safety questions would apply to perceptions of marketplace transactions. We compared Chinese business student responses with responses collected from the Canadian public and found some sizable differences. This led us to collect another sample from American business students to investigate whether the differences should be attributed to national or professional culture differences. We found that the business students in both the United States and China displayed similar patterns when judging marketplace phenomena. First, when the market shifts, the Canadian public respondents as well as the business students considered it fair for a firm to protect its reference profit at its transactors' expense, but the Chinese and U.S. business students moved one step further by considering it acceptable for a firm to increase such profit at the expense of its transactors. Second, the Canadian public and the American and Chinese business students were all affected by framing. Third, the Canadian public and the business students demonstrated different expectations of ethical standards that they themselves and their service providers would follow, with Canadians treating people equally and business students expecting differential treatments. 
The patterns of our findings are consistent with previous studies finding some differences and some similarities between people from China and North America or other cultures (e.g., Armstrong, 1996; Ho \& Chang, 1994; Ralston et al., 1992; Weber \& Hsee, 1998; Wimalasiri, Pavri, \& Jalil, 1996; Yates \& Lee, 1996). Further research in North America and China should search for the reasons behind similarities and differences between the general publics and between different professional subgroups.

Although our business students in both the United States and China responded similarly, we expected that their reasoning may diverge. An American business student may feel that it is important to let each individual have the freedom to charge whatever price the person wants and that will result in a healthy economic market. Such reasoning gives each individual an equal economic role. A Chinese business student may feel no obligation to fairly treat any specific individual consumer but still come to the same conclusion that any price is acceptable. Another difference may be the scope of the transaction. Hampden-Turner and Trompenaars (1993) claimed that Americans tend to focus on the smallest possible unit of economic exchange-a single transaction. In contrast, according to Ambler (1994), Chinese ask whether a long-term pattern of behavior is ethical or unethical rather than focusing on any particular transaction.

When we present our research on health and safety issues in seminars, invariably a person from a Western country wonders why we ask the two questions of: "What is fair?" and "What will you do?" Westerners tend to say: "Of course you'll do what's fair." Chinese appear to tend to separate the two concepts more. So what is unfair may be best to do. We have conducted a follow-up study with the Chinese public that presents current issues in China such as intellectual property rights, corruption, and wage differentials and asks both if these scenarios are fair or unfair and if they are acceptable or unacceptable. The distinction between fairness and acceptability merits further research.

Such cross-national and cross-professions marketplace phenomena should not be ignored by businesses. For example, different opinions on firms' reference transactions and reference prices suggest different pricing and employee benefit strategies. The fact that all the groups are similarly affected by framing hints that the kinds of Western marketing technologies that utilize framing can be transferred to the China market without much revising. Different ethical standards can lead to different negotiation tactics. Finally, large corporations that want to undertake health care or environmentally sensitive projects in China will benefit from a good understanding of the fairness opinions that they may encounter.

We are aware of the vagueness of the fairness concept itself. For example, there are no exact counterparts of the word fairness in the French and German languages. Even in English and Chinese, where fairness as a word does exist, there is still no single clear definition of fairness. (The Chinese equivalent of fairness is gong ping, in which gong means public and ping means balance.) In addition, it is often inter- 
changeable with other words, such as equity (in English) or reasonable (in Chinese), which indicates a possibly different focus in the twodifferent cultures. However, the exact definition of fairness does not pose a problem to us, because even though people may not have a single shared definition of fairness, they can still answer what activity is fair and what is not. Also, just like other kinds of human perceptions, fairness opinions are likely to be evolving. Future consumer ethics research should trace the ever-changing marketplace opinions with longitudinal studies.

\section{ACKNOWLEDGMENTS}

This research was supported by Grant SBR-9605826 from the National Science Foundation's Decision, Risk, and Management Science Program. This grant was awarded to L. Robin Keller and Wen-Qiang Bian to support Wen-Qiang Bian's dissertation research. The University of California, Irvine, Graduate School of Management also provided student travel funds.

We are grateful for comments by the referees and the guest editor, Julie R. Irwin, which prompted us to conduct another survey. We are especially grateful for help by Mei-Zen Tu of Shanghai Jiao Tong University and Hui-Hua Deng in Tomen (Shanghai) Corporation in collecting the data and for their valuable comments on the research. We thank Rong "Elaine" Zhang, Jeffery L. Guyse, and Michael Rylaarsdam of University of California, Irvine, for research assistance in data tabulation, survey administration, and article preparation.

\section{REFERENCES}

Ambler, T. (1994). Marketing's third paradigm: Guanxi. Business Strategy Review, 5, 69-80.

Armstrong, R. W. (1996). The relationship between culture and perception of ethical problems in international marketing. Journal of Business Ethics, 15, 1199-1208.

Baron, J., Gowda, R., \& Kunreuther, H. (1993). Attitudes toward managing hazardous waste: What should be cleaned up and who should pay for it? Risk Analysis, 13, 183-192.

Bian, W.-Q., \& Keller, L. R. (1999). Consumers' economic norms in the People's Republic of China (Working Paper). Irvine: University of California.

Bian, W.-Q., \& Keller, L. R. (in press). Chinese and Americans agree on what's fair, but disagree on what's best in societal decisions affecting health and safety risks. Risk Analysis.

Boisot, M., \& Child, J. (1996). From fiefs to clans and network capitalism: Explaining China's emerging economic order. Administrative Science Quarterly, 41, 600-628.

Cateora, P. R. (1993). International marketing (8th ed.). Homewood, IL: Irwin.

Chu, H. (1998, August 2). Troubles rise as flooding punishes China. Los Angeles Times, p. Al.

Diamond, J. (1998, July 19). China launch center called unsafe. Orange County Register, pp. 2, 25, 27.

Frank, R. H., Gilovich, T., \& Regan, D. T. (1993). Does studying economics inhibit cooperation? Journal of Economic Perspectives, 7, 159-171.

Groves, M. (1998, July 22). Study finds widening gap in milk prices. Los Angeles Times, pp. D1, D8.

Hall, E. T. (1976). Beyond culture. Garden City, NY: Anchor Press/Doubleday.

Hampden-Tumer, C., \& Trompenaars, A. (1993). The seven cultures of capitalism. New York: Doubleday. 
Ho, J., \& Chang, C. J. (1994). Does national culture or professional knowledge affect auditors' probability conjunction judgments? A study of the United States versus Taiwan. International Journal of Accounting, 29, 189-205.

Hsieh, Y. W. (1967). The status of individual in Chinese ethics. In C. A. Moore (Ed.), The Chinese mind (pp. 307-322). Honolulu: University of Hawaii (East-West Center) Press.

Hui, C. H., Triandis, H. C., \& Yee, C. (1991). Cultural differences in reward allocation: Is collectivism the explanation? British Journal of Social Psychology, 30, 145-157.

In O.C., milk isn't a bargain at big stores. (1998, July 22). Orange County Register, p. B1.

Irwin, J. R. (1994). Buying/selling price preference reversals: Preference for environmental changes in buying versus selling modes. Organizational Behavior \& Human Decision Processes, 60, 431-457.

Irwin, J. R., Jones, L. E., \& Mundo, D. (1996). Risk perception and victim perception-The judgement of HIV cases. Journal of Behavioral Decision Making, 9, 1-22.

Irwin, J. R., Slovic, P., Lichtenstein, S., \& McClelland, G. H. (1993). Preference reversals and the measurement of environmental values. Journal of Risk and Uncertainty, 6, 5-18.

Kahneman, D. H., Knetsch, J. L., \& Thaler, R. H. (1986). Fairness as a constraint on profit seeking: Entitlements in the market. The American Economic Review, 76, 728-741. (See also the 1986 article "Fairness and Assumptions of Economics" in The Journal of Business, Volume 59, pp. S285-S300.)

Keller, L. R., \& Sarin, R. (1988). Equity in social risk: Some empirical observations. Risk Analysis, 8, 135-146.

Keller, L. R., \& Sarin, R. (1995). Fair processes for societal decisions involving distributional inequalities. Risk Analysis, 15, 135-146.

Kunreuther, H. (1986). Comments on Plott and Kahneman, Knetsch, and Thaler. The Journal of Business, 59, S329-S338.

Leung, K., \& Bond, H. M. (1984). The impact of cultural collectivism on reward allocation. Journal of Personality and Social Psychology, 47, 793-804.

Markoczy, L. (1997). Measuring beliefs: Accept no substitutes. Academy of Management Journal, 40, $1228-1242$.

Markoczy, L. (1998, February). Us and them. Across the Board, 44-48.

Mulkern, A. (1998, July 22). Higher milk prices fit big stores' strategy. Orange County Register, p. B4.

Ralston, D. A., Gustafson, D. J., Elsass, P. M., Cheung, F., \& Terpstra, R. H. (1992). Eastern values: A comparison of managers in the United States, Hong Kong, and the People's Republic of China. Journal of Applied Psychology, 77, 664-671.

Sokolowska, J., \& Tyszka, T. (1995). Perception and acceptance of technological and environmental risks: Why are poor countries less concerned? Risk Analysis, 15, 733-743.

Trompenaars, F. (1994). Riding the waves of culture: Understanding diversity in global business. New York: Irwin.

Vaughan, E., \& Nordenstam, B. (1991). The perception of environmental risks among ethnically diverse groups. Journal of Cross-Cultural Psychology, 22, 29-60.

Wagenaar, W. A., Keren, G., \& Lichtenstein, S. (1988). Islanders and hostages: Deep and surface structures of decision problems. Acta Psychologica, 67, 175-189.

Weber, E. U., \& Hsee, C. R. (1998). Cross-cultural differences in risk perception, but cross-cultural similarities in attitudes towards perceived risk. Management Science, 44, 1205-1217.

Wimalasiri, J. S., Pavri, F., \& Jalil, A. A. K. (1996). An empirical study of moral reasoning among managers in Singapore. Journal of Business Ethics, 15, 1331-1341.

Yates, J. F., \& Lee, J.-W. (1996). Chinese decision-making. In M. H. Bond (Ed.), The handbook of Chinese psychology (pp. 338-351). New York: Oxford University Press.

Yau, H. M. (1994). Consumer behaviour in China-Customer satisfactions and cultural values. London: Routledge.

Yu, P.-L. (1991). Habitual domains. Operations Research, 39, 869-876. 


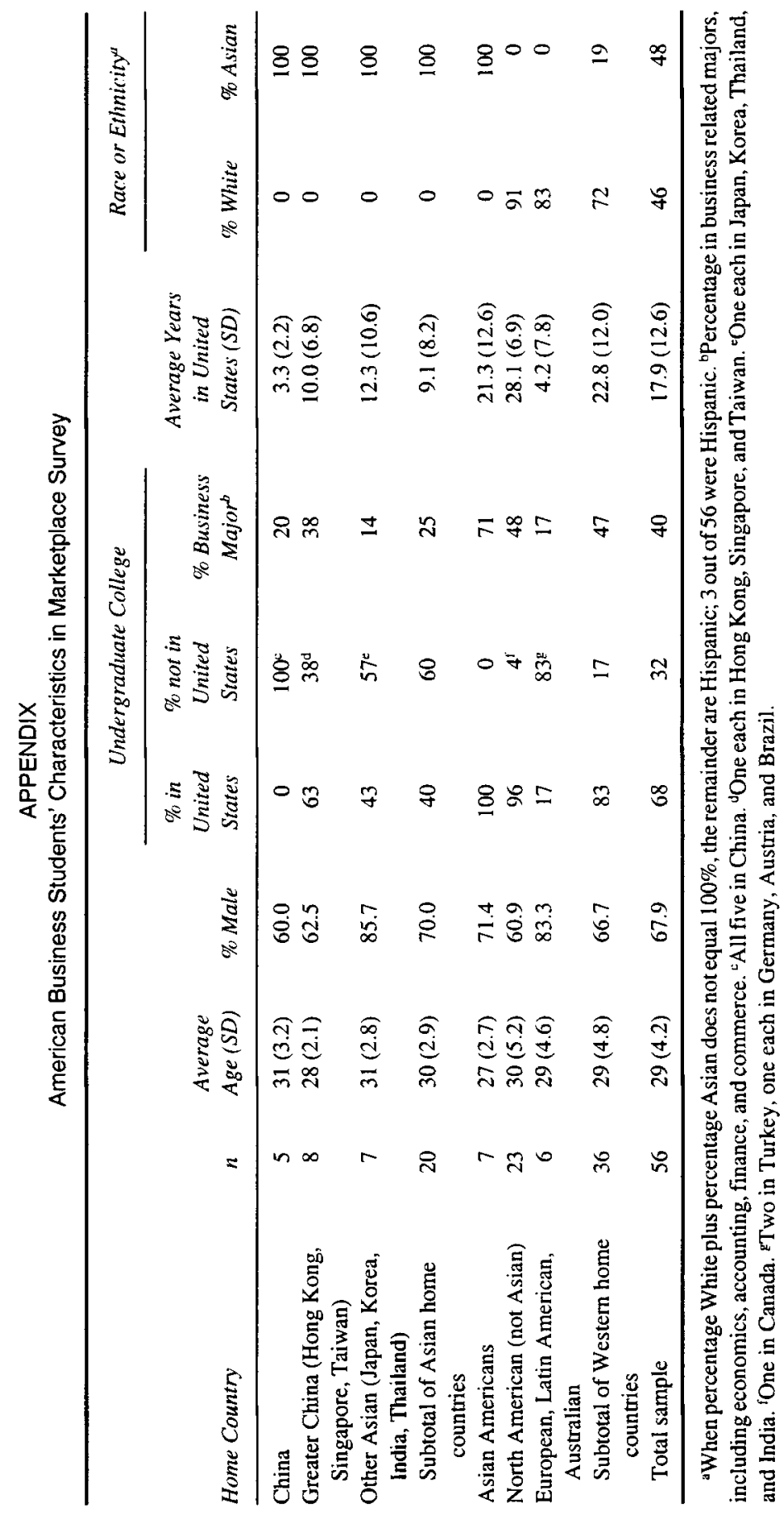

